Canadian Journal of Higher Education Revue canadienne d'enseignement supérieur

Volume 44, No. 2, 2014, pages 68 - 84

\title{
The Inquiry Network: A model for promoting the teaching-research nexus in higher education
}

Marcy Slapcoff \& dik Harris

McGill University

\begin{abstract}
We describe how our teaching and learning centre developed a model, founded on Boyer's notion of scholarship, to explore the nature of the teachingresearch nexus. At the core of this model is the Inquiry Network, a faculty learning community whose members moved from exploring the links between their own teaching and research to creating institution-wide resources to promote student learning. Working together, the members of the community developed a framework for learning outcomes that instructors can use in coursework to cultivate students' understanding of research and scholarship, regardless of discipline, academic level, or class size. The article recounts the process that led to the creation of the framework, and it considers the effectiveness of the process and the framework as a model for educational development and institutional change at a research-intensive university.
\end{abstract}

\section{Résumé}

Nous décrivons comment notre centre d'enseignement et d'apprentissage a élaboré un modèle fondé sur la notion de la mission professorale selon Boyer, pour examiner la nature du lien entre l'enseignement et la recherche. $\mathrm{Au}$ cœur de ce modèle se trouve le " réseau d'enquête ", une communauté d'apprentissage du corps professoral dont les membres sont passés de l'exploration des liens entre leurs propres recherches et enseignements à la création de ressources institutionnelles visant à promouvoir l'apprentissage chez les étudiants. Ensemble, les membres de la communauté ont élaboré un cadre de résultats d'apprentissage que les instructeurs peuvent utiliser en lien 
avec les travaux de cours afin de cultiver la compréhension des étudiants envers la recherche et la mission professorale, indépendamment de la discipline, du niveau scolaire ou de la taille des classes. L'article relate le processus qui a mené à la création du cadre, et examine l'efficacité du processus et du cadre en guise de modèle de perfectionnement de l'enseignement et de changement institutionnel au sein d'une université fortement axée sur la recherche.

\section{Introduction}

This article describes McGill University's teaching and learning centre's model for exploring the nexus between teaching and research. The model, which involved the creation of a faculty learning community, the Inquiry Network, was McGill's response to the Boyer Commission's (1998) call to make research-based learning the standard for undergraduates in research-intensive universities. Often, an important aspect of this challenge is that instructor-researchers do not see any link between their research, their teaching, and their undergraduate students' learning, and as expected, this was the case for the members of our learning community. However, working together, the members eventually came to articulate the link in terms of a framework that sets forth a series of learning outcomes for undergraduate courses. These outcomes were not discipline specific, but were clearly related to Boyer's definition of scholarship (1990), which goes beyond the traditional understanding of research as discovery and includes the concepts of integration, application, and teaching. It is in this sense that we will use the terms "research and scholarship" to denote all activities of professional academics in the pursuit of knowledge.

In the article, we first describe the context of our institution, underlining the important support that we received from the administration. We then give a brief introduction to the literature on the teaching-research nexus, followed by a description of the evolution of our faculty learning community, the Inquiry Network, since it created a framework for addressing the nexus. We detail important stages in the development of the community's ideas, in the educational development of the members, and in the expansion of the initiative to the institution as a whole. While we believe that our model could be applicable within all institutions of higher learning, we propose that it may be particularly appropriate for research-intensive universities where the integration of research and teaching is frequently a strategic objective.

McGill University is a research-intensive university in eastern Canada. It has a total student enrolment of approximately 38,000, of whom 27,000 are undergraduates; there are 11 faculties and approximately 1,700 tenured and tenure-stream faculty. The criteria for promotion and tenure address teaching, research, and service; although teaching and research are usually weighted equally, there is still a wide-spread perception that research is first among these equals. There are both university and faculty awards for excellence in teaching and even some awards within individual departments.

There is a well-established centre for teaching and learning, offering a range of services to academic staff and graduate students, including program development, individual consultations, and university-wide workshops. Much of this work is founded on principles implemented in the centre's Course Design and Teaching Workshop (Saroyan \& Amundsen, 2004), which values and builds upon participants' expertise in their disciplines - expertise that is usually more closely related to content knowledge and research 
than to pedagogical content knowledge (L. S. Shulman, 1986). Over the years, the alumni of this workshop have become an important resource for the centre and for the university, serving on innumerable committees and working groups.

\section{Establishing Institutional Support}

In recent years, there has been explicit encouragement from the university administration for initiatives to improve the student experience of learning. Among these has been the relocation of the teaching and learning centre to a more central location on campus and an increase in the number of its staff so that it has been able to greatly expand its services and occupy a position of leadership in numerous university-wide initiatives. Within this context, in 2008-2009 the administration mandated the centre to lead an initiative to promote the teaching-research nexus (more information about this initiative can be found at at www.mcgill.ca/tls/projects/nexus). This followed the university's publication of several strategic documents in which the teaching-research nexus was given high priority and reflected a worldwide interest in the subject (Beckman \& Hensel, 2009; Brew, 2003; Elrod, Husic, \& Kinzie, 2010; Elton, 2005; Kuh, 2008). Specifically, the mandate saw beyond individual supervision - the most obvious way in which professors can link teaching, research, and scholarship - and promoted the use of coursework to enhance undergraduate students' understanding of how research and scholarship contribute to knowledge production. Coursework in this context refers to required, complementary, or elective courses that are assigned a credit rating based on the number of weekly contact hours.

\section{Defining the Nexus}

Our main challenge was that many faculty members did not believe in the teachingresearch nexus: they opposed the existence of a link between their teaching and research, arguing that no connection was possible at the undergraduate level. Even in a researchintensive university, some argue that there is no relation between quality (or quantity) of research and quality of undergraduate teaching (Feldman, 1987; Prince, Felder, \& Brent, 2007). However, the authors of the meta-analysis most often quoted to support this point of view (Hattie \& Marsh, 1996) make it very clear that "The fundamental issue is what we WISH the relation to be, and then we need to devise policies to enact this wish" (Hattie \& Marsh, 2004 , p.147). Such policies are clearly envisaged by the Boyer Commission (1998), which wrote,

research universities share a special set of characteristics and experience a range of common challenges in relation to their undergraduate students. If these challenges are not met, undergraduates can be denied the kind of education they have the right to expect at a research university, an education that, while providing the essential features of general education, also introduces them to inquiry-based learning. (p.1)

Our challenge was to find a definition of the teaching-research nexus that would resonate with faculty. Only when there was a common understanding of the nexus could we determine how instructors could better integrate teaching and research to benefit student learning within undergraduate courses, and how the value added in this way could be supported and recognized by the institution. Inevitably, this led us to face the varying conceptions of what constitute research and teaching (Zubrick, Reid, \& Rossiter, 2001). 
To this end, various authors have attempted to redefine the scope and nature of "research," including the disciplinary dimension (Brew, 1999, 2001; Smeby, 1998). Neumann (1993) observes that a broad view of research encompasses a wide range of activities, because "[e]ach discipline has its own knowledge paradigm which determines the appropriate manner of approaching a research problem" (p. 98). In support of this view, she quotes the work of Biglan (1973) and Becher (Becher, 1994; Becher \& Trowler, 2001), who have classified different disciplinary endeavours according to two orthogonal axes: pure-applied and soft-hard. For example, a natural science such as physics is a pure-hard discipline, concerned with an over-riding explanation of universal phenomena, while a social science such as education is an applied-soft discipline, more concerned with functional knowledge and practical application.

Equally, there are discussions relating the teaching-research nexus to the differing nature of teaching in different disciplines (Lueddeke, 2003; Moses, 1990; Neumann, 2001; Neumann, Parry \& Becher, 2002). Jenkins (1996) makes the case that educational development - development of teaching - takes place within the disciplinary context and must therefore take account of disciplinary allegiances. The various authors in Hativa and Marincovich (1995) demonstrate not only that there are disciplinary differences in teaching and learning but also there are variations in orientations toward instruction, and Smeby (1998) documents significant disciplinary variations in the times spent on different aspects of teaching and preparation.

However, for us, a more productive perspective is the link between teaching and research that is afforded by "learning." Brew and Boud (1995,) propose that,

Learning .... is the vital link between research and teaching. It is a shared process in these two enterprises. Learning acts as a powerful intervening factor in all of the studies attempting to demonstrate a relationship between teaching and research since it is the process whereby an individual teacher - researcher, student, learner - comes to know. (p. 268)

In this context, learning is far more than the accumulation of disciplinary content. It encompasses, certainly, the different ways of thinking and knowing in the different disciplines (Entwistle, 2005) and corresponds closely to active or inquiry learning as described by Bransford, Brown, and Cocking (2000) and, in the university context, by Lee (2004). Restricting the scope of the nexus to coursework would also build on the existing expertise of our teaching and learning centre.

\section{Selecting a Common Definition}

In view of this focus on student learning, the work of Healey and Jenkins (Healey, 2005; Healey \& Jenkins, 2009; Jenkins, 2000, 2004; Jenkins \& Healey, 2005) proved an effective starting point. Their definition of the nexus is best summarized by the framework in Figure 1, where different strategies for linking research, teaching, and learning are distributed among four quadrants (Healey, 2005), presenting a range of possibilities for integrating research into coursework. It makes clear that research does not take place only in the lab or in the field, and it provides a vocabulary for discussing the nexus, makes explicit the link to student learning, and allows instructors to easily identify ways in which they are already engaging students with research. 


\section{Emphasis on Research Content}

\begin{tabular}{l|l}
\multicolumn{2}{c}{$\begin{array}{c}\text { Student Focused } \\
\text { Students as Participants }\end{array}$} \\
$\begin{array}{l}\text { Research-tutored } \\
\text { Curriculum emphasizes } \\
\text { learning focused on } \\
\text { students writing and } \\
\text { discussing papcrs or } \\
\text { cssays }\end{array}$ & $\begin{array}{l}\text { Research-based } \\
\text { Curriculum emphasizes } \\
\text { students undertaking } \\
\text { inquiry-based learning }\end{array}$ \\
\hline $\begin{array}{l}\text { Research-led } \\
\text { Curriculum is structured } \\
\text { around teaching subject } \\
\text { content. }\end{array}$ & $\begin{array}{l}\text { Research- } \\
\text { oriented } \\
\text { Curriculum emphasizes } \\
\text { tenching proccsscs of } \\
\text { knowledgc } \\
\text { construction } \\
\text { in the subject }\end{array}$ \\
\multicolumn{2}{c}{ Teacher Focused } \\
Students as Audience
\end{tabular}

Emphasis on Research Processes and Problems

Figure 1. The Teaching-Research Nexus ${ }^{1}$

${ }^{1}$ From Healey, M. in Reshaping the University: New Relationships Between Research, Scholarship and Teaching, R. Barnett, Ed. (p. 70), 2005, Buckingham, UK: McGrawHill/Open University Press. Reproduced with the kind permission of Open University Press. All rights reserved.

Discussions began at a two-day symposium on improving the links between undergraduate teaching and research through coursework. It included a keynote speech, workshops, and presentations by instructors and their students, and was open to all members of the university community. Symposium goals were to inform the community of the initiative, to generate excitement for its development, and to seek out potential partners. More specifically, it provided the opportunity to share the Healey framework and to receive feedback on its application within our institutional context.

The symposium was enthusiastically received, signaling acceptance of the framework, but it was the presentations that had the greatest significance and impact because they illustrated concretely how to embed research into undergraduate courses within the constraints of disciplinary and contextual differences. Indeed, it became clear, through conversations with numerous members of the academic staff, that the need was for a concrete, individualized approach to the teaching-research nexus by providing examples to instructors across the university. While many examples exist in the literature (Healey \& Jenkins, 2009: Jenkins \& Healey, 2005; Lee, 2004), the greatest impact was from home-grown examples illustrating how faculty from McGill had successfully integrated their teaching and research. However, it was also evident that by grounding the project in an accepted theoretical framework and providing a definition of the nexus, the Nexus Project had gained legitimacy among our core audience, university professors, whose first steps in any research project would include a survey of the relevant literature and a definition of terms. 


\section{Launching a Cross-Disciplinary Faculty Learning Community}

After the symposium, it was clear that the teaching-research nexus was still not part of the vernacular at our institution. To promote its importance and clarify the link to student learning, we required a group of faculty members who would recognize its utility and advocate its value on campus. Consequently, after a review of materials employed at other institutions (Jenkins \& Healey, 2005; Lee, 2004; Willison \& O'Regan, 2007), we launched the Inquiry Network, a faculty learning community (Cox, 2004) of a dozen instructors drawn from across the university, together with two facilitators from the teaching and learning centre and a graduate-student assistant. The group's twofold mandate was to examine its members' own teaching practice, determining how to better integrate research and teaching, and to propose to the university how to promote the teaching-research nexus in ways that would benefit undergraduate student learning.

The learning community format was chosen because it seemed to us the most appropriate to our research-intensive institution. Almost all our instructors were active researchers, accustomed to being part of research networks where their work is subject to constant debate with colleagues. Choosing a learning community format allowed them to participate in a familiar fashion, despite their lack of familiarity with the subject matter and despite the fact that, more often than not, their teaching had been a private endeavour occurring behind closed doors (L. S. Shulman, 2005). The learning community - like any mentoring network (Johnson, 2007) or community of practice - allowed each of them to contribute their individual disciplinary expertise and concerns, thus strengthening a sense of collegiality amongst instructors from different disciplines and promoting an open and inquiry-based approach to their educational development (Sachse-Akerlind \& Quinlan, 2001).

Although the literature provided some guidelines and examples, the cross-disciplinary, inquiry-based approach was necessary because the examples were not necessarily adaptable to our institutional setting or for contexts that varied immensely according to class size, academic level, and discipline. Additionally, the cross-disciplinary nature of the group ensured that members generally remained focused on the task at hand and did not digress into content-specific discussions. Members of the network came together because of their interest in linking teaching and research, but in the end, the network has served a much larger purpose because it has enabled members to share reflections about teaching and learning in general and learn from one another in a mutually respectful environment.

\section{Taking an Inquiry-Based Approach}

Thus, from the beginning in August 2009, the facilitators adopted an inquiry-based approach. To start the discussion, they asked the members: "What do you teach? What do you research? What is the relationship between your teaching and your research?" The responses were entirely consistent with the literature (Hattie \& Marsh, 1996) and quickly revealed that most of them found little connection between these two activities. A chemist teaching classes of several hundred asserted that exposing his students to research was impossible because no lab could accommodate that number of students; an experienced geologist stated that he did not conduct research; a physicist noted that undergraduates need years to learn the fundamentals before being able to grasp the abstract nature of 
frontier research. The issue therefore challenged the very existence of the network: if the links between teaching and research were in doubt, how could the teaching-research nexus become the means to promote student learning?

The Inquiry Network met regularly throughout the fall semester to tackle this question. Many interesting yet meandering discussions took place since among the members there was no common culture of research (Brew, 1999, 2003) and no common language for discussing teaching and learning (Harris, 2004). The topics explored included students' cognitive development, Bloom's taxonomy, inquiry-based learning, assessment for learning, and even students' resistance to change. However, there was some preliminary discussion of the linkage between research and scholarship, in the sense of Boyer (1990; Boyer Commission, 1998), leading to a preliminary appreciation of the Healey framework. Finally, by November, a clear direction emerged: the members themselves would analyze their own undergraduate courses to determine how they currently initiated students into research and scholarship in their discipline. Is it through the discussion of research findings, the use of research methods, and/or the fostering of curiosity and higher-order thinking skills? In effect, the members came to understand their "need to reflect upon their own ways of understanding subject matter and consider the implications of this for the ways in which they teach and bring their students into a relationship with that subject matter" (Prosser, Martin, Trigwell, Ramsden, \& Middleton, 2008, p.13).

Three members were invited to present to the network a description of one course in which their students were exposed to research or scholarship. Each was asked to describe his or her course (including level, context, and student background), the subject material, the learning outcomes, and the assessment strategies, and then to describe the role of research or scholarship. So that these presentations were accessible and intelligible, each presenter first met with the facilitators to structure his or her presentation according to a common educational framework. It was convenient to use the centre's framework for course design and teaching workshops (Saroyan and Amundsen, 2004), which included a basic introduction to methods such as concept mapping and curriculum-developing concepts such as instructional objectives, active learning, and assessment. This was necessary because, although the members were committed to teaching and learning and had years of experience, some lacked a foundation in the corresponding theoretical vocabulary.

These presentations led to discussions about where in each course the teaching-research nexus emerged and how it could be augmented. The specific examples also helped the members of the network to work together in trying to apply the categories of the Healey framework to real situations and therefore to wrestle with their meaning. Importantly, They came to the important recognition that within each category there could be learning corresponding to all levels of Bloom's cognitive taxonomy (Weston \& Cranton, 1986). New categories emerged that they felt better reflected their own understanding of the teaching-research nexus and which used a vocabulary that was more familiar to them. Ultimately, these new categories were themselves replaced, but at that time they became our reference point: they are shown in Figure 2. 


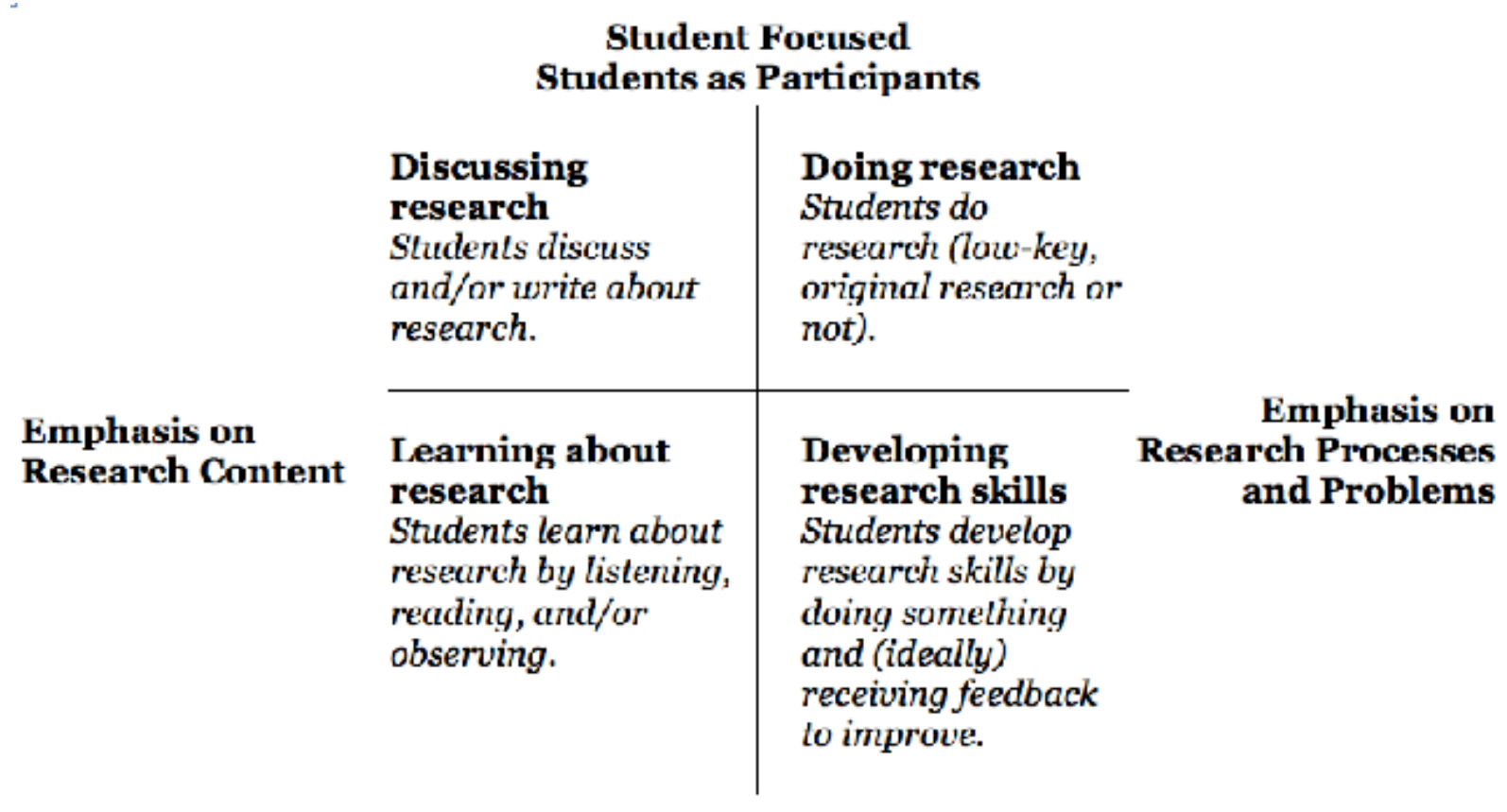

\section{Teacher Focused Students as Audience}

Figure 2. Revised Healey Framework for the Nexus. ${ }^{2}$

${ }^{2}$ Adapted from Healey, M. in Reshaping the University: New Relationships Between Research, Scholarship and Teaching, R. Barnett, Ed. (p. 70), 2005, Buckingham, UK: McGraw-Hill/Open University Press.

The discussions during the three course presentations also revealed the value of articulating learning outcomes and aligning these with specific strategies for instruction and assessment. To extend this approach, each member who had not presented was asked to complete a questionnaire describing a course where undergraduates were engaged with research or scholarship. The summary of the questionnaire was presented to the network in a way that linked course content, learning outcomes, and instructional and assessment strategies to each quadrant of Figure 2. This challenged the members to examine their learning outcomes, to identify areas where there was a lack of coherence among course elements, and to consider the appropriateness of their instructional and assessment strategies. The facilitators grounded the discussion in the actual experience of the members and only then addressed concepts of alignment and of formal and informal assessment.

As the members reviewed their contributions and shared their reflections with one another, they began to assemble a set of generic learning outcomes for promoting students' learning about research and scholarship. The intention was to distill the outcomes into a form that might ultimately be useful to instructors from all faculties. However, recognizing that the work done to date was just a start, they ended the first year with the recommendation that input be sought from a larger, more diverse group of faculty. It was also clear to them that some training would be beneficial so as to ensure that all of the group 
shared a common vocabulary and understanding of teaching and learning. Over time, motivated by their interest in working together, they had identified a way to address the complex challenge of promoting the teaching-research nexus at our institution.

\section{Creating Common Pedagogical Foundations}

Year 2 began with 13 members in the network. Some from the previous year were unable to continue, but new members had been recruited from faculties that had previously not been represented. A workshop in two parts served as an introduction. Part 1, an adaptation of the centre's teaching and learning workshop (Saroyan \& Amundsen, 2004), introduced the notion of learning-centred teaching and the purpose of defining and aligning course content, learning outcomes, and strategies for instruction and assessment. Part 2 defined the nexus, reviewing its importance for the institution and then describing the past work of the network.

The workshop was successful in that network members became more familiar with each other's teaching contexts and disciplinary homes, and they began to use similar terms, drawn from the educational literature, to describe their academic work, thus allowing them to communicate across disciplinary boundaries. In addition, the group identity was beginning to form - returning members openly encouraged the participation of the new, and new members were curious about what had been done in the past and enthused about contributing their perspectives. The qualities necessary for "community in Faculty Learning Communities" (Cox, 2004, p.19) were intentionally fostered by the facilitators, who aimed to create an atmosphere of safety, trust, and openness, and a sense of collaboration, personal relevance, and linkage to the institutional mission.

The workshop also served to shift the subsequent discussion towards learning outcomes and instructional strategies. It became clear that the Healey framework (Figure 1) and the revised Healey framework (Figure 2) were limited in this respect, in having no direct link to relevant learning outcomes or to the assessment of students' progress toward these goals. The decision was made to develop a set of learning outcomes to reflect different aspects of research and scholarship: outcomes that instructors could use to articulate existing aspects of their courses or as inspiration for designing new ways of embedding research and scholarship in them.

Through a process of individual reflection and writing, complemented by small-group discussions and feedback exchanges, each member developed learning outcomes for one undergraduate course. The feedback focused on clearly articulating where research and scholarship were being promoted, what students were learning, and how this could be assessed. This was a key learning opportunity that allowed members to see how writing and speaking are effective tools for inquiry-based learning (Anson \& Dannels, 2004) and led to discussions about providing the same experience for students.

\section{Developing a Shared Conceptual Framework for Learning Outcomes}

From the discussions three categories of outcomes emerged that summarized how students could deepen their understanding of research in any discipline. These were the key results of our collective endeavor: 
1. In terms of knowledge, students need to develop an awareness that knowledge is dynamic, not static.

2. In terms of methodology, students need to become familiar with the methods used to gather, organize, analyze, interpret, and evaluate data and source material.

3. In terms of communication, students need to learn how to use discussion and writing not only as mechanisms for reporting on work but also as processes to help them develop and communicate their thinking.

This framework emerged from two years of dialogue and debate, and represents the shared understanding of the network members at that time. In more recent discussions, it has been decided that the third outcome, which cites discussion and writing as tools to develop critical thinking, will be broadened to include forms of creative expression such as music, dance, and the visual arts. This development is a clear sign that the network sees these outcomes not as unchangeable but as items that evolve as the conversation continues. Indeed, the members of the network intend to encourage colleagues in new faculty learning communities to view the framework as a springboard for discussion and, if needed, to modify the outcomes to better reflect their particular instructional needs and shared conceptions of the teaching-research nexus.

To illustrate how the general outcomes of the framework could be made more precise, the network members developed a more concrete, discipline-specific set of outcomes. The result was the list in the appendix. This list became the basis of the network's framework for the nexus and the reference point for all future discussions. Network members then set out to create a resource for fellow instructors where they could demonstrate how these outcomes could be embedded within courses. This resource included examples from each member illustrating how they had used one outcome to guide the selection of instructional and assessment strategies. Although these examples were not comprehensive, they allowed network members to validate the usefulness of the framework by illustrating how particular outcomes could be tailored to contexts that varied according to discipline, academic level, and class size. Future plans for the network include the collection and analysis of data from students to determine how changes made by instructors to instructional and assessment strategies benefit student learning and engagement.

In short, the network concluded that there is no single formula for integrating research into coursework: how best to enhance students' understanding of research requires careful examination of course content, goals, and assignments as well as students' background and motivation. Although individual instructors can make these determinations, the network members concluded that it is more productive to work with colleagues from other disciplines because cross-disciplinary discussions expose unquestioned assumptions and promote the discovery of alternative strategies. In addition, although the outcomes in the framework represented in the appendix are designed primarily for individual instructors, they will have greater institutional impact if they are also consulted by departments and faculties (Boyer, 1990). The three categories in the appendix for developing students' understanding of research could provide a foundation for the design and sequencing of curricula so that students will acquire experience in all three areas on completing a given program. Our teaching and learning unit is currently exploring the possibility of working with an individual department to test out this approach. 


\section{Involving the Community at Large}

As Year 2 of the Inquiry Network came to a close, the members began to think about sharing the results of their collaboration and about involving more members of the institution - faculty, staff, and students - in the exploration of the nexus. Rather than emphasizing an attempt to influence institutional policy, which they saw as merely presenting the "result" of their deliberations - the shared conceptual framework - the members were agreed that it was important to share the process through which they had arrived at consensus via presentations and workshops in faculties and departments, which appeal to our instructors' ever-present pre-occupation with research. Ideally, it was envisaged that such initiatives would lead to the creation of new learning communities that would use the exiting framework as a springboard for discussion: at the present time, some workshops and presentations have indeed taken place, and university-wide resources have also been created. The success of the network has depended on the involvement of its members: during the two years of working together, it was rare that even one member would miss a regular monthly meeting. Seemingly, the network provided an incentive for both personal development and meaningful contribution although such a high level of involvement should not be taken for granted.

Two principal factors appear to have contributed to the ongoing sense of commitment and enthusiasm, and it will be crucial that these are incorporated into efforts to expand the project. The first of these is the valuing of the members' expertise in their own disciplines, as in the well-established Course Design and Teaching Workshop (Saroyan \& Amundsen, 2004) and the acknowledgement of their own view of the teaching research nexus. The second is the deliberate introduction of a common language to facilitate conversations across disciplinary boundaries while still respecting members' identities as scholars in their own fields. It stimulated the process of argumentation and debate, thus replicating academic practices that the members had previously only experienced within their disciplines. For those who become involved with the network in the future, it will be important to provide opportunities for becoming familiar with this language. Not surprisingly, these two factors correspond in large measure to the first two "attributes" of a faculty learning community (Patrick \& Fletcher, 1998; Cox, 2001; G. M. Shulman, Cox, \& Richlin, 2004). The challenge for the future is therefore to develop the remaining attributes while maintaining the sense of involvement and commitment of the network's members.

\section{Summary and Conclusion}

The Nexus Project seems a particularly effective model for promoting the teaching-research nexus at McGill, a research-intensive university, because it builds on the strengths and interests of our faculty members, almost all of who are active researchers. Challenging them to integrate aspects of their research into coursework is an effective means of engaging them in the improvement of student engagement and learning. It is as much the process of engagement as it is the end product - the framework - that is important. That said, however, the process is a complex one and requires that instructors have the time and support necessary for designing or redesigning their courses. This support could take many forms, but we have found a faculty learning community to be most effective starting point because it includes opportunities for reflection and cross-disciplinary dialogue. 
To summarize, the model has two essential components:

1. The framework for learning outcomes

- incorporates the essentials for embedding research/scholarship in undergraduate coursework

- contains examples that faculty members can use to design aspects of their courses to incorporate research, regardless of class size, level and discipline

- is open to modification so that future groups can create new outcomes, based on the existing set

2. The collaborative process

- values participants' expertise and identities as scholars in their own disciplines introduces a common language to facilitate conversations across disciplinary boundaries

- creates a theoretical framework that resonates with participants who are accustomed to a research environment

- supports participants in developing their own approach to linking teaching and research

At the core of the model is the Inquiry Network. Even as it currently exists, the network is a significant step toward the creation of an intellectual community (Patrick \& Fletcher, 1998, p. 162). Its power is that its members are involved as scholars in their own right, even as they learn the language that allows them to communicate across disciplinary boundaries. Its value as a tool for educational development arises because its initial focus on the scholarship of discovery - research - resonates strongly within a research-intensive university. The members of the network, present and future, are potential agents of change in their respective disciplinary communities and in the university at large, reaching out in ways scarcely possible for a teaching and learning centre with finite resources.

\section{Acknowledgments}

The authors wish to thank the members of the Inquiry Network, especially Mariela Tovar and Eva Dobler, for contributing to the development of the model. We also thank Cynthia Weston and Laura Winer for providing feedback during the writing process.

\section{References}

Anson, C. M., \& Dannels, D. P. (2004). The heart of the matter: Writing, speaking, and inquiry-guided learning. In V. S. Lee (Ed.), Teaching and learning through inquiry (pp. 219-228). Sterling, VA: Stylus.

Becher, T. (1994). The significance of disciplinary differences, Studies in Higher Education, 19(2), 151-161.

Becher, T. \& Trowler, P. R. (2001). Academic tribes and territories, Buckingham, UK: McGraw-Hill/Open University Press.

Beckman,M., \& Hensel, N.(2009). Making explicit theimplicit: Defining undergraduate research, CUR Quarterly, 29(4), 40-44.

Biglan, A. (1973). The characteristics of subject matter in different academic areas, Journal of Applied Psychology, 57, 195-203. 
Boyer, E. L. (1990). Scholarship reconsidered: Priorities of the professoriate, Stanford, CA: The Carnegie Foundation for the Advancement of Teaching.

Boyer Commission on Educating Undergraduates in the Research University. (1998). Reinventing undergraduate education: A blueprint for America's research universities. Stony Brook, NY: State University of New York at Stony Brook for the Carnegie Foundation for the Advancement of Teaching. Retrieved from http://hdl.handle.net/1951/26012

Bransford, J. D., Brown, A. L., \& Cocking R. R. (2000). How people learn: Brain, mind, experience and school, Washington, DC: National Academy Press.

Brew, A. (1999). Research and teaching: Changing relationships in a changing context, Studies in Higher Education, 24(3), 291-301.

Brew, A. (2001). Conceptions of research: A phenomenographic study. Studies in Higher Education, 26(3), 271-85.

Brew, A. (2003). Teaching and Research: New relationships and their implications for inquiry-based teaching and learning in higher education, Higher Education Research and Development, 22(1), 3-18.

Brew, A., \& Boud, D. (1995). Teaching and research: Establishing the vital link with learning. Higher Education, 29, 261-273.

Cox, M. D. (2001). Faculty learning communities; Change agents for transforming institutions into learning organizations. To Improve the Academy, 19, 69-93.

Cox, M. D. (2004). Introduction to faculty learning communities, New Directions for Teaching and Learning, 97, 5-23.

Elrod, S., Husic, D., \& Kinzie, J. (2010). Research and discovery across the curriculum, PeerReview, 12(2), 4-8.

Elton, L. (2005). Scholarship and the research and teaching nexus. In R. Barnett (Ed.), Reshaping the University: New relationships between research, scholarship and teaching (pp. 108-118). Buckingham, UK: McGraw-Hill/Open University Press.

Entwistle, N. (2005). Ways of thinking and ways of teaching across contrasting subject areas. Retrieved from http://www.etl.tla.ed.ac.uk//docs/etlISL2005.pdf

Feldman, K.A. (1987). Research productivity and scholarly accomplishment of college teachers as related to their instructional effectiveness: A review and exploration. Research in Higher Education, 26(3), 227-298.

Harris, d. (2004). The challenge to unlearn traditional language. In A. Saroyan, \& C. Amundsen (Eds.), Rethinking teaching in higher education, (pp. 169-8). Sterling, VA: Stylus.

Hativa, N., \& Marincovich, M. (Eds.) (1995). Disciplinary differences in teaching and learning: Implications for practice. San Francisco, CA: Jossey-Bass.

Hattie, J., \& Marsh, H. W. (1996). The relationship between research and teaching: A meta-analysis, Review of Educational Research, 66(4), 507-542. 
Hattie, J., \& Marsh, H.W. (2004) One journey to unravel the relationship between research and teaching, Colloquium proceedings of Research and teaching: Closing the divide? Retrieved from http://www.education.auckland.ac.nz/webdav/site/education/ shared/hattie/docs/ relationship-between-research-and-teaching-\%282004\%29.pdf

Healey, M. (2005). Linking research and teaching: Exploring disciplinary spaces and the role of inquiry-based teaching. In R. Barnett, (Ed.), Reshaping the university: New relationships between research, scholarship and teaching (pp. 67-78). Buckingham, UK: McGraw-Hill/Open University Press.

Healey, M., \& Jenkins A. (2009). Developing undergraduate research and enquiry. Heslington, UK: Higher Education Academy. Retrieved from http://www.heacademy. ac.uk/assets/York/documents/resources/publications/DevelopingUndergraduate_ Final.pdf

Jenkins, A. (1996). Discipline-based educational development, International Journal for Academic Development, 1, 50-62

Jenkins,A. (2000). Review of the research and scholarly evidence on teaching research relationships in higher education. Retrieved from http://www.heacademy.ac.uk/assets/ Documents/resources/database/id97_Summary_Review_of_the_Research_and_ Scholarly_Evidence_on_Teaching_Research_Relationships_in_Higher_Education.rtf

Jenkins, A. (2004). A guide to the research evidence on teaching-research relations. Retrieved from http://www.heacademy.ac.uk/assets/York/documents/ourwork/ research/id383_guide_to_research_evidence_on_teaching_research_relations.pdf

Jenkins, A., \& Healey, M. (2005). Institutional strategies to link teaching and research: A summary. Retrieved from http://www.heacademy.ac.uk/resources/detail/ ourwork/evidencenet/Summaries/institutional_strategies_to_link_teaching_and_ research_a_summary

Johnson, W. B. (2007). On being a mentor: A guide for higher education faculty, Mahwah, NJ: Lawrence Erlbaum.

Kuh, G. D. (2008). High-impact educational practices: What they are, who has access to them, and why they matter, Washington, DC: Association of American Colleges and Universities.

Lee, V. S. (2004). Teaching and learning through inquiry. Sterling, VA: Stylus

Lueddeke, G. R. (2003). Professionalising teaching practice in higher education: a study of disciplinary variation and teaching-scholarship, Studies in Higher Education 28(2), 213-228

Moses, I. (1990). Teaching, research and scholarship in different disciplines, Higher Education, 19(4), 351-375.

Neumann, R. (1993). Research and scholarship: Perceptions of senior academic administrators, Higher Education, 25, 97-110.

Neumann, R. (2001). Disciplinary differences and university teaching. Studies in Higher Education, 26(2), 135-146. 
Neumann, R., Parry, S., \& Becher, T. (2002). Teaching and learning in their disciplinary context, Studies in Higher Education, 27(4), 405-417.

Patrick, S.K. \& Fletcher, J.J. (1998). Faculty developers as change agents: Transforming colleges and universities into learning organizations, To Improve the Academy, 17, 155-70.

Prince, M. J., Felder, R. M., \& Brent, R. (2007). Does faculty research improve undergraduate teaching? An analysis of existing and potential synergies, Journal of Engineering Education, 96(4), 283-294.

Prosser, M., Martin, E., Trigwell, K., Ramsden, P., \& Middleton H., (2008). University academics' experience of research and its relationship to their experience of teaching. Instructional Science, 36, 3-16.

Sachse-Akerlind, G., \& Quinlan, K. (2001). Strengthening collegiality to enhance teaching, research and scholarly practice: An untapped resource for faculty development. To Improve the Academy, 19, 306-322.

Saroyan, A., \& Amundsen, C. (Eds.). (2004). Rethinking teaching in higher education. Sterling, VA: Stylus.

Shulman, G. M., Cox, M. D., \& Richlin L. (2004). Institutional considerations in developing a faculty learning community program, New Directions for Teaching and Learning, 97, 41-49

Shulman, L.S. (1986). Those who understand: Knowledge growth in teaching, Educational Researcher, 15(2), 4-14.

Shulman, L. S. (2005). Signature pedagogies in the professions', Daedelus, 134(3), 52-59

Smeby, J-C. (1998). Knowledge production and knowledge transmission. The interaction between research and teaching at universities, Teaching in Higher Education, $3(1), 5^{-20 .}$

Weston, C., \& Cranton, P. (1986). Selecting instructional strategies, Journal of Higher Education, 57(3), 260-288.

Willison, J., \& O’Regan, K. (2007). Commonly known, commonly not known, totally unknown: A framework for students becoming researchers. Higher Education Research and Development, 26(4), 393-409.

Zubrick, A., Reid, A., \& Rossiter, P. (2001). Strengthening the nexus between teaching and research. Curtin University of Technology, University of Ballarat, and University of Western Australia. Retrieved from http://reforma.fen.uchile.cl/ Papers/Strengthening\%20Nexus\%20Btw\%20Teaching\%20\&\%20Research\%20-\%20 Zubrick,\%20Reid,\%20Rossiter.pdf

\section{Contact Information}

Marcy Slapcoff

Teaching and Learning Services

McGill University

marcy.slapcoff@mcgill.ca 
Marcy Slapcoff is an educational developer at McGill University's Teaching and Learning Services, where she leads a university-wide initiative to promote the links between teaching, learning, and research. Marcy also develops and facilitates course design and teaching workshops and is involved in promoting sustainability in higher education.

dik Harris is an emeritus professor of physics and was founding director of the Tomlinson Project for University Level Science Education at McGill University. His research interests in education include the disciplinary context of teaching and learning, and the role of metacognition in physics problem solving. 


\section{Appendix}

\section{Inquiry Network Framework for Enhancing Students' Understanding Of Research: Three Categories of General Learning Outcomes with Examples.}

\section{Students develop an awareness that knowledge is dynamic, not static.}

1. Remember facts that are part of the established consensus in a field and understand that consensus is still evolving.

2. Identify patterns and consistencies in the knowledge base of a subject area or discipline.

3. Make connections between concepts within a subject area or discipline.

4. Tolerate uncertainty and accept that there is much that we do not know.

5. Analyze purported improvements in a subject area or discipline and evaluate their worth.

6. Be aware that there are ethical dimensions to both the production and representation of existing knowledge and the generation of new knowledge.

7. Recognize the relationship between knowledge and cultural frameworks.

2. Students develop skills to gather, organize, analyze, interpret, and evaluate data and source material.

1. Become aware of the basic processes of knowledge production and the conventions that govern research in a given subject area or discipline.

2. Pose well-formulated questions, develop viable thesis statements/hypotheses, and generate informed and well-supported arguments.

3. Locate appropriate resources and literature relevant to the subject area or discipline.

4. Develop observational skills.

5. Develop psychomotor skills (e.g., operating equipment).

6. Develop critical thinking and questioning skills.

7. Develop teamwork skills.

8. Perform tasks specific to the subject area or discipline.

9. Develop skills in critical reading of scholarly and non-scholarly publications, including identifying false premises and uncovering implicit assumptions.

10. Develop skills in ethical research practices.

11. Replicate aspects of existing research with increasing levels of autonomy.

12. Conduct original research.

3. Students use discussion and writing to develop and communicate their understanding of a research topic, subject area, or discipline.

1. Use writing to explore and think about a research topic, subject area, or discipline: writing to learn, not merely to record.

2. Develop writing skills to report on research following discipline-specific conventions.

3. Collaborate with peers, share ideas, and exchange feedback to advance understanding of the subject area.

4. Use writing to communicate ideas about research to specialist and non-specialist audiences. 